\title{
Trends in Summer Season Climate for Eastern Europe and Southern Russia in the Early 21 st Century
}

\author{
Maria G. Lebedeva, ${ }^{1}$ Olga V. Krymskaya, ${ }^{1}$ Anthony R. Lupo, ${ }^{1,2}$ \\ Yury G. Chendev, ${ }^{1}$ Alexandr N. Petin, ${ }^{1}$ and Alexandr B. Solovyov ${ }^{1}$ \\ ${ }^{1}$ Belgorod State University, 85 Pobedi Ulitsa, Belgorod 308015, Russia \\ ${ }^{2}$ Department of Soil, Environmental and Atmospheric Sciences, University of Missouri, 302 ABNR Building, \\ Columbia, MO 65211-7250, USA
}

Correspondence should be addressed to Maria G. Lebedeva; lebedeva_m@bsu.edu.ru

Received 10 February 2015; Accepted 4 August 2015

Academic Editor: Ismail Gultepe

Copyright (C) 2016 Maria G. Lebedeva et al. This is an open access article distributed under the Creative Commons Attribution License, which permits unrestricted use, distribution, and reproduction in any medium, provided the original work is properly cited.

\begin{abstract}
The goal of this research is to evaluate changes in temperature and precipitation in the Central Chernozem Region of southwestern Russia during the summer and relate these to large-scale circulation types and synoptic circulation processes. Some of these circulation regimes result in extreme weather conditions over the region. Using a classification system for Northern Hemisphere large-scale flow regimes and observations of weather within the Central Chernozem Region, the role of individual synoptic patterns in the formation of weather anomalies was identified. Also, comparing the periods 1981-2010 and 1971-2000, the mean summer temperatures increased by $0.6^{\circ} \mathrm{C}$ regionally. During the most recent decade the increase was $1.3^{\circ} \mathrm{C}$. Total precipitation for the summer increased over the 20th century and was characterized by less variability during the second half when compared to the first half. However, in the beginning of the 21st century, precipitation has decreased during the growing season, but variability has increased. The increase in summer temperatures and increased variability in precipitation were then linked to an increase in the occurrence of weather regimes associated with warm anomalies and blocking. Finally, the results of this study can be used to translate larger-scale seasonal or climate forecasts to the regional scale.
\end{abstract}

\section{Introduction}

The changes in the atmospheric circulation over the past few decades have been linked to global changes in temperature and have had a significant influence on the dominant weather conditions in many locations on both the large and regional scales. Recently, there have been several articles which demonstrate that hemispheric and/or regional weather is strongly influenced by teleconnections as well as changes in climate (e.g., [1-8]). These changes can also be associated with the more frequent occurrence of extreme or abnormal values of temperature and precipitation in some places and fewer extremes in others (e.g., [4-8]). There is widespread public concern that extreme weather will result in more costly disasters for local and regional economies. One example would be drought, which is associated generally with reductions in agricultural output.

There have also been changes in shorter term climate variability related to El Niño and Southern Oscillation (ENSO) that can be related to changes in phases of longer term variability such as the Pacific Decadal Oscillation [3, 8-10]. In [3], it was shown that ENSO precipitation variability in the Midwest United States changed when the phase of the PDO changed. For example, the authors found that ENSO related variability was stronger during the warm phase of the PDO and less pronounced during the cool phase, and this result was similar to that found in [10]. Recently, [8] found a strong relationship with the PDO in the long term climate of the Northwest United States. Also, [9] found that El Niño became stronger in the latter part of the 20th century compared with 
that of the middle part of the century. But recently, [3] and others have shown that El Niño has become weaker and that these changes in ENSO are consistent with longer term variability. Additionally, studies of the occurrence of extreme weather conditions in the Central Chernozem Region of western Russia have also been performed [11-13], and they showed that the occurrence of extreme and hazardous conditions has increased in the region.

In a recent study, [14] examined climate variability on very long timescales and also shorter timescales. The authors in [14] found that precipitation had increased during the last part of the 20th century in this region. In spite of increased precipitation in the region, [15] found that summer season precipitation variability in the southwest part of Russia was related to the transition phase of ENSO. In particular, the authors in [15] found that drier summers during the 1970 to 2013 period were associated with the transition to El Niño years and steady state La Niña conditions, while more favorable summers for agricultural production were associated with steady state ENSO neutral conditions.

This research will examine trends and variability in summer temperature and precipitation within the Central Chernozem Region (CCR) of southwestern Russia over a longer time period. This area is in a zone of moderate continental-type climate (e.g., $[16,17])$. Additionally, this work will link the summer season temperature and precipitation conditions to the occurrence of large-scale and synoptic weather types by using a classification scheme of predominant Northern Hemisphere (NH) weather types [11]. This study will present this classification scheme, which is unique in the literature, and has potential application for research and operational forecasting. Also, this work will examine the duration and intensity of temperature and precipitation anomalies associated with zonal and meridional atmospheric circulation types. Then, these circulation types also can be associated with periods of extreme weather and climatic characteristics [11-13]. Additionally, for application to agricultural and economic activity, studies of climate variability on the regional and local scale are more appropriate and useful than those on the global scale (e.g., $[18,19])$.

\section{Data and Methodology}

2.1. Data. The precipitation and temperature data used in this study for Belgorod region can be obtained from the All Russia Research Institute of Hydrometeorological InformationWorld Data Centre (RIHMI-WDC http://meteo.ru/) and also from [20]. These were provided in Celsius for temperature and millimeters for precipitation. The NH circulation classification scheme was derived originally by B. L. Dzerdzeyevskii, published in [11], and then modified and used by [21, 22]. The role of individual circulation types as related to the basic climatic conditions of the region and the occurrence of anomalous conditions were identified. Lastly, the National Center for Atmospheric Research/National Centers for Environmental Prediction reanalyses [23] were used to create the maps for the large-scale flow regimes, in particular the $500 \mathrm{hPa}$ geopotential heights at 1200 UTC. This time period is close to midday in the study region and also contains more observations than other time periods.

2.2. Large-Scale Flow Regimes. In these references above there are 13 basic types of circulation classifications (Figure 1) for the $\mathrm{NH}$ as a whole derived using six different sectors $\left(60^{\circ}\right.$ longitude). In this study, these are more generally classified into four groups based on the synoptic character of the flow (cyclonic or anticyclonic) in the region for both the warm and cold seasons. In the original work, the predominance of zonal or meridional circulations within each of the six sectors was used as the main indicator for classification. The flows were characterized based on the location of primary troughs and ridges in jet stream within the $\mathrm{NH}$. The original data also provide flow trajectories derived from $500 \mathrm{hPa}$ isohypses and associated with $500 \mathrm{hPa}$ trough and ridge systems on synoptic maps.

Variants for each of these 13 circulation types are characterized by differences in the location of the troughs and ridges and their associated polar air intrusions or prominent cyclone systems. The total number of variants for the $\mathrm{NH}$ is 42 synoptic types, and these are described in great detail by [21]. The four general types identified here (and 13 major categories in [11]) are described briefly below.

(i) Zonal Circulation (Types 1 and 2). These are characterized generally by the absence of cold air outbreaks in the $\mathrm{NH}$ and the predominance of wave numbers two to five. Type 1 is more dominant in the cold season and characterized by wave numbers three and four (Figure 1(a)), while type 2 is more predominant during the warm season (Figure 1(b)). There are two variants of type 1 and three for type 2 based primarily on the location of $\mathrm{NH}$ high pressure centers at $500 \mathrm{hPa}$. For type 1, there are major high pressure centers over the oceans and the Eurasian continent. In the CCR, type la is characterized by high pressure at the surface, while, with type $1 \mathrm{~b}$, there is low pressure over the region (Table 1 ). Type 2 can also be associated with ridging at $500 \mathrm{hPa}$ (Figure 1(b)) or even a stationary anticyclone (blocking) over the study region as defined by [24]. On the surface in the CCR, types $2 \mathrm{a}$ and $2 \mathrm{~b}$ are characterized by high pressure, while type $2 \mathrm{c}$ is characterized by low pressure (Table 1). Type 1 can be characterized by a high or low North Atlantic Oscillation Index [25], while type 2 generally is associated with a high index (zonal) flow.

(ii) Zonal, Breaking Waves (Types 3-7). These are characterized by one polar air mass invasion or strong trough and three strong cyclone events throughout the $\mathrm{NH}$ and wave number three or four at $500 \mathrm{hPa}$. Type 3 (Figure 1(c)) is predominantly warm season flow regime at $500 \mathrm{hPa}$, with a polar outbreak over the Atlantic region (lower NAO Index (Figure 1(c))). This type is characterized by surface low pressure over the CCR (Table 1). Type 4 has three variants at $500 \mathrm{hPa}$ with the cold air outbreak occurring primarily over eastern Europe and Russia including CCR for types $4 \mathrm{a}$ and $4 \mathrm{~b}$ (Figure 1(d)). Type $4 \mathrm{a}$ occurs primarily during the cold season and types $4 \mathrm{~b}$ and $4 \mathrm{c}$ occur during the warm season. On the surface in the CCR, types $4 \mathrm{a}$ and $4 \mathrm{~b}$ are primarily anticyclonic and type 


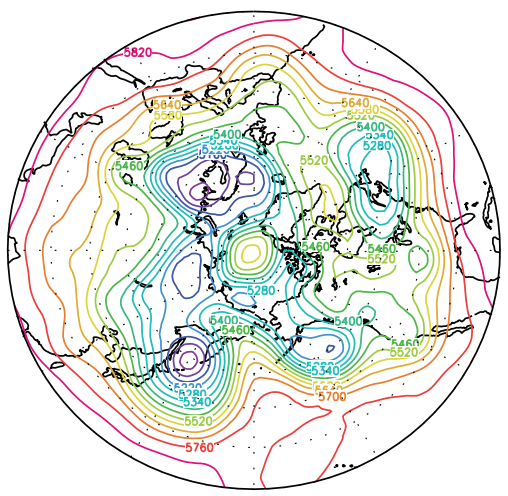

(a)

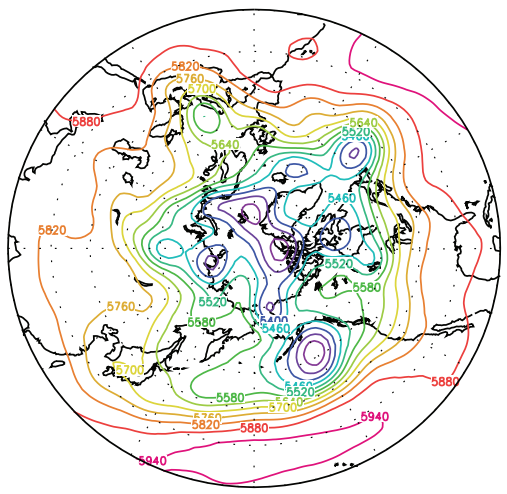

(d)

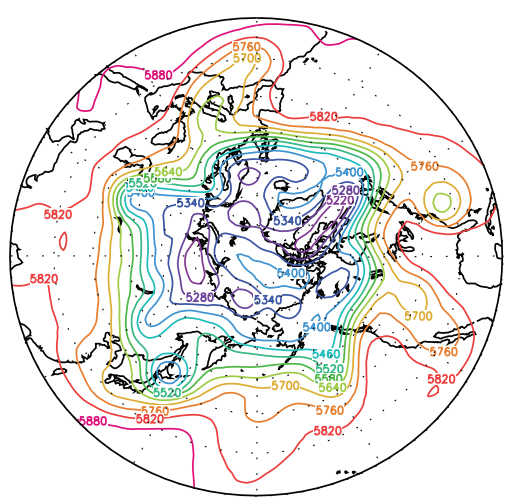

(g)

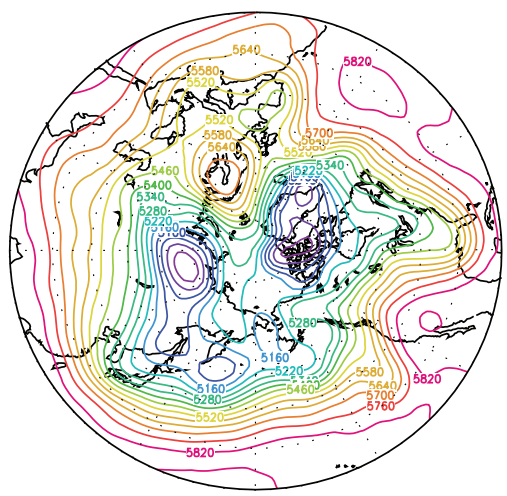

(j)

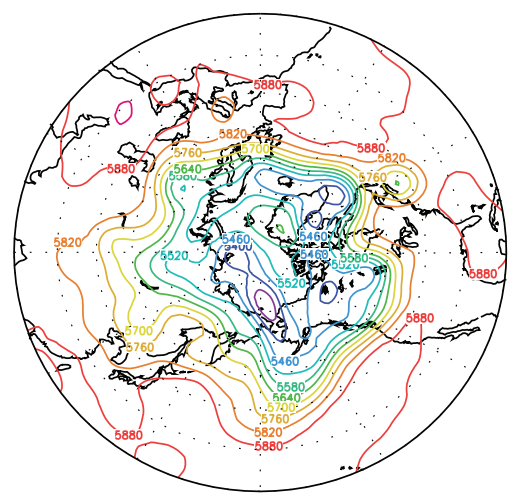

(b)

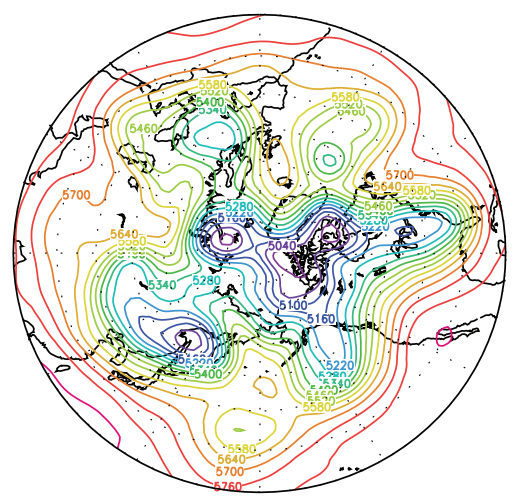

(e)

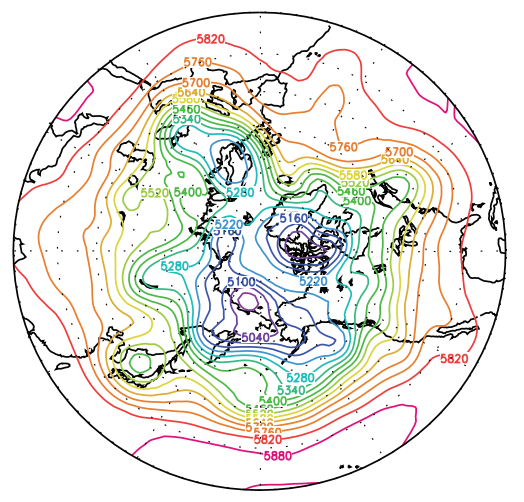

(h)

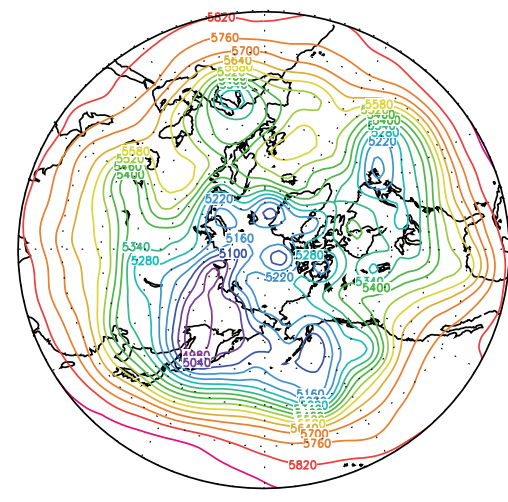

(k)

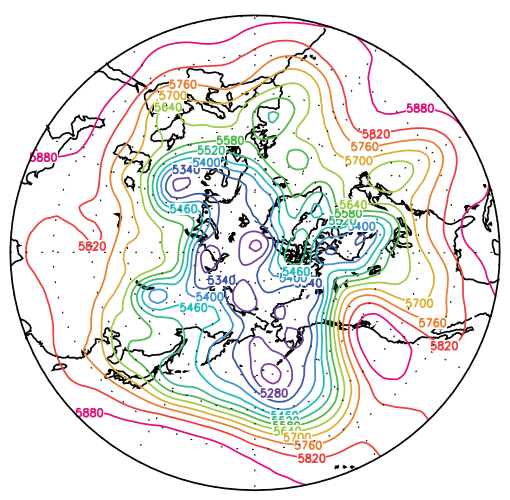

(c)

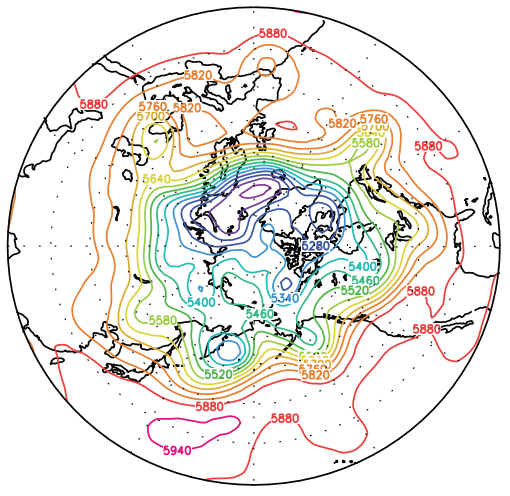

(f)

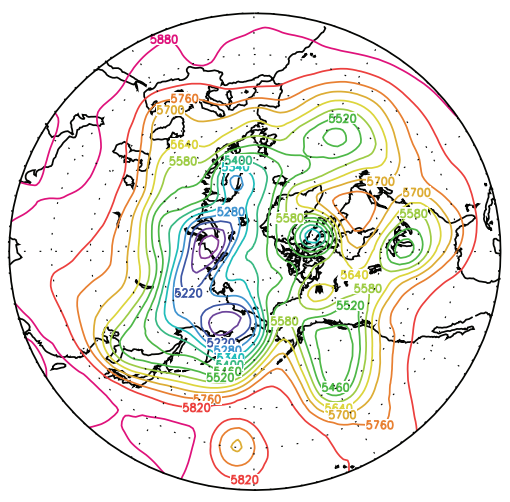

(i)

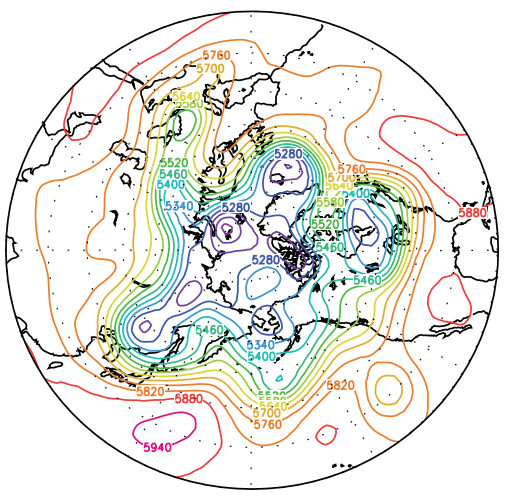

(1)

Figure 1: Continued. 


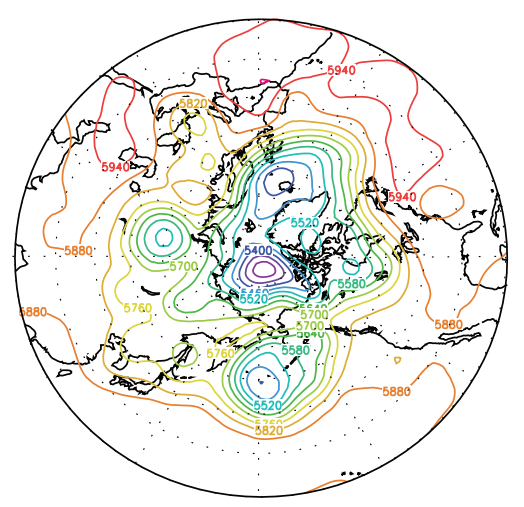

$(\mathrm{m})$

FIgURE 1: Example of the large-scale circulation types for each of the 13 categories using the 1200 UTC $500 \mathrm{hPa}$ height field. The contours are in color and the interval is $60 \mathrm{~m}$ and (a) type 1: 21 March 2006, (b) type 2: 27 August 2008, (c) type 3:15 May 2008, (d) type 4: 1 June 2010, (e) type 5: 13 December 2010, (f) type 6: 27 September 2009, (g) type 7: 7 May 2007, (h) Type 8: 11 November 2007, (i) type 9: 13 May 2006, (j) type 10: 6 January 2006, (k) type 11: 12 February 2010, (l) type 12: 16 October 2011, and (m) type 13: 8 July 2010.

TABLE 1: The large-scale flow regime characterization as related to circulation character over the Central Chernozem Region.

\begin{tabular}{|c|c|c|}
\hline Surface pressure field description & Large-scale flow type & $\begin{array}{l}\text { Air mass movement in the East } \\
\text { European sector }\end{array}$ \\
\hline \multicolumn{3}{|l|}{ Winter } \\
\hline \multicolumn{3}{|l|}{ (I) Anticyclonic } \\
\hline (A) Arctic anticyclones & $4 \mathrm{a}, 4 \mathrm{~b}, 8 \mathrm{bw}, 10 \mathrm{a}, 10 \mathrm{~b}$ & Longitudinal north \\
\hline (B) Ridging-Azores anticyclone & $5 \mathrm{a}, 5 \mathrm{~b}, 8 \mathrm{cw}, 11 \mathrm{a}, 11 \mathrm{c}, 11 \mathrm{~d}, 12 \mathrm{~d}$ & Latitudinal Western \\
\hline (C) Siberian anticyclone- & $1 a, 5 b, 13 w$ & Stationary flow/blocking \\
\hline \multicolumn{3}{|l|}{ (II) Cyclonic } \\
\hline (A) Western cyclones & $4 c, 11 b$ & Latitudinal western \\
\hline (B) Southern cyclones & $\begin{array}{l}1 \mathrm{~b}, 3,5 \mathrm{~d}, 6,7 \mathrm{aw}, 7 \mathrm{bw}, 8 \mathrm{a}, 8 \mathrm{dw}, 9 \mathrm{~b} \\
12 \mathrm{a}, 12 \mathrm{bw}, 12 \mathrm{cw}\end{array}$ & Longitudinal southern \\
\hline \multicolumn{3}{|l|}{ Summer } \\
\hline \multicolumn{3}{|l|}{ (I) Anticyclonic } \\
\hline (A) Arctic anticyclones & $4 \mathrm{~b}, 8 \mathrm{ds}, 10 \mathrm{a}, 10 \mathrm{~b}$ & Longitudinal north \\
\hline (B) Ridging-Azores anticyclone & $2 \mathrm{~b}, 6,7 \mathrm{as}$ & Latitudinal western \\
\hline (C) Siberian anticyclone & $9 \mathrm{a}, 2 \mathrm{a}, 7 \mathrm{bs}, 13 \mathrm{~s}$ & Stationary/blocking \\
\hline \multicolumn{3}{|l|}{ (II) Cyclonic } \\
\hline (A) Southwestern cyclones & $\begin{array}{l}2 \mathrm{c}, 3,4 \mathrm{a}, 4 \mathrm{c}, 8 \mathrm{a}, 8 \mathrm{bs}, 8 \mathrm{cs}, 9 \mathrm{~b}, 12 \mathrm{bs}, \\
12 \mathrm{cs}\end{array}$ & $\begin{array}{l}\text { Latitudinal western and } \\
\text { longitudinal southern }\end{array}$ \\
\hline
\end{tabular}

$4 \mathrm{c}$ is cyclonic (Table 1). Type 5 (Figure $1(\mathrm{e})$ ) is characterized by a strong zonal Atlantic jet stream extending across the northern part of Europe at $500 \mathrm{hPa}$ and also a strengthened Mediterranean southwesterly jet stream extending over the study region for type $5 \mathrm{~d}$ (not shown). This type is primarily cold season flow type, with the cold air outbreak occurring over eastern Asia (Figure 1(e)). This type has four variants with the primary differences being between the location, strength, and direction of the jet stream over Europe. On the surface in the CCR (Table 1), high (low) pressure is associated with types $5 \mathrm{a}$ and $5 \mathrm{~b}$ (types $5 \mathrm{c}$ and $5 \mathrm{~d}$ ). Type 6 is primarily warm season configuration very similar to type $5 \mathrm{~d}$ except that the polar intrusion is over the west or mid-Pacific region (Figure 1(f)). For type 6 (Table 1), there is surface low (high) pressure over the CCR during the winter (summer). Type 7 (Figure $1(\mathrm{~g})$ ) is characterized by a polar intrusion occurring over eastern (western) North America [type 7a (type 7b)] at $500 \mathrm{hPa}$. For each type 7 there are a summer and winter variant characterized by poleward (equatorward) flow over the CCR in winter (summer) for type $7 \mathrm{a}$ and the opposite for type $7 \mathrm{~b}$. This is consistent with the presence of low pressure to the west (east) in the winter and high pressure to the west (east) in the summer at the surface (Table 1).

(iii) Meridional NH Circulation (Types 8-12). These are characterized by multiple polar intrusions, two to four strong $500 \mathrm{hPa}$ cyclones and meridional flow of wave number three or four. Type 8 has the most variants (seven) and the primary 
characteristic is that there are two cold air outbreaks present in each case, indicating highly meridional circulation. Type $8 \mathrm{a}$ (Figure 1(h)) is characterized by cold air outbreaks in the Midwest or northeast USA and Europe and strong southerly flow over the CCR at $500 \mathrm{hPa}$. The occurrence of this type peaks during the transition seasons and especially in May and November. Types $8 \mathrm{~b}-8 \mathrm{~d}$ are characterized by cold air outbreaks over the western Europe and East Asia, Central Asia and the Pacific, and the Atlantic and Central Asia, respectively. Each of these has a cold and warm season variant differing primarily in strength. Types $8 \mathrm{~b}$ and $8 \mathrm{~d}$ can be associated with ridging or blocking over the CCR during the warm season and low pressure for types $8 \mathrm{c}$ and $8 \mathrm{~d}$ during the cold season (not shown). On the surface (Table 1) for type 8 in the CCR, low pressure predominates for the warm season and cold season, with the exception that during the winter types $8 \mathrm{a}$ and $8 \mathrm{~b}$ are associated with anticyclones. Type 9 (Figure 1(i)) has two variants at $500 \mathrm{hPa}$ and both are characterized cold air outbreaks off each coast of North America (Type 9a-Figure 1(i)), and over the central Pacific and Atlantic (Type 9b). Over the CCR on the surface (Table 1), type $9 \mathrm{a}$ is characterized by high pressure and type $9 \mathrm{~b}$ by southerly flow and low pressure. Type $9 \mathrm{a}$ is primarily warm season weather pattern and type $9 \mathrm{~b}$ is a transition season weather pattern.

Type 10 is characterized by two cold air outbreaks and has two variants at $500 \mathrm{hPa}$ (Figure 1(j)). In type 10a, the cold air is located over the western USA and the CCR, while, for type 10b, the cold air outbreak is in the Eastern Pacific and east of the CCR (Figure 1(j)). Type 10a has no preferred season, while type $10 \mathrm{~b}$ is primarily warm season event. In Figure $1(j)$, there is blocking located to the west of the CCR and on the surface (Table 1) type 10 is associated only with anticyclones over the CCR. Type 11 (Figure 1(k)) at $500 \mathrm{hPa}$ has four variants, and all of these are cold season events characterized by colder air over the western and central USA and the northern Siberia region of Russia. Types 11a, 11c, and 11d (type 11b) are associated with high (low) pressure over the CCR at the surface (Table 1). Type 12a is a strongly amplified wave number four pattern at $500 \mathrm{hPa}$ (Figure 1(1)) with cold air outbreaks occurring over the extreme east and west of North America and also over Eurasia. Type 12a (Figure 1(l)) occurs primarily during the transitions seasons, especially spring (April, May), and is associated with southerly flow and low pressure across the CCR on the surface (Table 1). Types $12 \mathrm{~b}$ and $12 \mathrm{c}$ are similar to type $12 \mathrm{a}$ but are wave number three events each with a summer and winter variant. The difference is in the strength of the cold air outbreaks which occur over North America, central Asia, and the Atlantic for $12 \mathrm{~b}$ and over central North America, western Europe, and eastern Asia for type $12 \mathrm{c}$.

(iv) Azores Anticyclone (Type 13). This flow type is characterized by the absence of polar intrusions, wave number three, and has two variants at $500 \mathrm{hPa}$ (Figure $1(\mathrm{~m})$ ). Both types $13 \mathrm{w}$ and $13 \mathrm{~s}$ are characterized by high pressure at $500 \mathrm{hPa}$ and on the surface over the CCR or are centered just to the east (Table 1). Azores Anticyclone is generally characterized by a high NAO index over the Atlantic region. Type 13 is often associated with blocking, and type 13s was the pattern associated with the prolonged summer blocking event of 2010 over the CCR (e.g., $[15,26])$.

\section{Climatological Study}

3.1. Large-Scale and Local Flow Regimes versus Strong Temperature and Precipitation Anomalies. In order to assess the impact of large-scale atmospheric circulation on the temperature and precipitation regimes in the CCR and surroundings, the classification scheme described above was used, covering the period from 1899 to the present time [20-22]. This made it possible to combine the large-scale weather patterns into the cyclonic and anticyclonic groups identified by this study. Within each group the large-scale circulation pattern may vary in the type and location of air masses over the rest of the $\mathrm{NH}$, but the synoptic processes in the CCR and surrounding regions will be very similar (Table 1 ).

The territory of the CCR is located in an area close to two prominent climatological features, the Mediterranean Storm Track and the Eastern European-western Russia blocking region (e.g., [24]), which makes this region an area of less variable weather conditions. This is particularly true with respect to the temperature regime, at which throughout the summer season the daily standard deviation is less than $2^{\circ} \mathrm{C}$. When temperatures are anomalous, this character generally extends to the entire region and beyond and is commensurate with the space scales of synoptic events. An example of this kind of anomaly would be the anomalous warmth that accompanied the blocking event of summer $2010[15,26]$. Therefore, we can use the Belgorodskoe-Fenino weather station to represent the climatological character of the region for the analysis of anomalous meteorological parameters during the winter and summer periods (e.g., [3] and references therein) and their correlation to atmospheric circulation types. This permanent weather station is in a climatologically suitable location and has provided a homogeneous series of observations since 1881 .

The correlation of circulation types to temperature and precipitation anomalies has been carried out by many authors in the past (e.g., $[1,27])$ and more recently (e.g., $[3,11,14$, $15,18,28-30])$. Also, this method of identifying circulation types and correlating these to regional climatic variables such as temperature and precipitation is used currently by the Laboratory of Climatology at the Institute of Geography in the Russian Academy of Sciences [11]. Additionally, the climatological time series data for daily air temperature and daily precipitation were evaluated for the 1971-2000 monthly and season means and then evaluated for the 1981-2010 information.

Table 2 presents the list of circulation types correlated with anomalies of mean daily values of temperature and precipitation at a confidence level greater than 0.80 . In the summer season positive anomalies of daily mean temperature in the CCR were associated with flow regimes of types. These are both characterized by southerly flow across the region and are occurring in advance of a surface cyclone (type $4 c)$ or with flow on the west side of the Siberian summer 
TABLE 2: Statistical characteristics of the circulation types and the corresponding meteorological characteristics.

\begin{tabular}{|c|c|c|c|c|c|c|}
\hline $\begin{array}{l}\text { Meteorological } \\
\text { characteristic }\end{array}$ & $\begin{array}{l}\text { Circulation } \\
\text { type }\end{array}$ & $\begin{array}{c}\text { Total number } \\
\text { of circulation } \\
\text { days }\end{array}$ & $\begin{array}{c}\text { Average } \\
\text { temperature } \\
\left({ }^{\circ} \mathrm{C}\right) \text { or daily } \\
\text { rainfall }(\mathrm{mm})\end{array}$ & $\begin{array}{l}\text { Average anomaly } \\
\text { of temp. and } \\
\text { precip. with } \\
\text { circulation type }\end{array}$ & $\begin{array}{c}\text { Standard } \\
\text { deviation of temp. } \\
\text { and precip. with } \\
\text { type }\end{array}$ & $\begin{array}{l}\text { Statistical } \\
\text { confidence }\end{array}$ \\
\hline 1 & 2 & 3 & 4 & 5 & 6 & 7 \\
\hline \multicolumn{7}{|c|}{ Winter } \\
\hline \multirow{4}{*}{$\begin{array}{l}\text { The average daily air } \\
\text { temperature, }{ }^{\circ} \mathrm{C}\end{array}$} & $4 \mathrm{c}$ & 18 & -12.5 & -5.1 & 3.7 & 0.99 \\
\hline & $12 \mathrm{bw}$ & 40 & -9.2 & -1.7 & 2.6 & 0.84 \\
\hline & $12 \mathrm{~d}$ & 47 & -10.0 & -2.6 & 2.6 & 0.98 \\
\hline & $13 w$ & 196 & -5.2 & 2.2 & 2.4 & 0.98 \\
\hline \multirow{6}{*}{$\begin{array}{l}\text { Average daily precipitation, } \\
\mathrm{mm}\end{array}$} & $1 b$ & 10 & 1.3 & -0.1 & 1.4 & 0.82 \\
\hline & $5 b$ & 24 & 0.9 & -0.5 & 1.5 & 0.81 \\
\hline & $7 \mathrm{aw}$ & 23 & 1.0 & -0.3 & 1.2 & 0.93 \\
\hline & $11 d$ & 45 & 1.7 & 0.4 & 1.9 & 0.96 \\
\hline & $12 \mathrm{bw}$ & 40 & 1.8 & 0.5 & 1.8 & 0.96 \\
\hline & $12 \mathrm{cw}$ & 25 & 0.8 & -0.5 & 1.7 & 0.87 \\
\hline \multicolumn{7}{|c|}{ Summer } \\
\hline \multirow{5}{*}{$\begin{array}{l}\text { The average daily air } \\
\text { temperature, }{ }^{\circ} \mathrm{C}\end{array}$} & $2 \mathrm{~b}$ & 55 & 17.8 & -0.6 & 1.7 & 0.90 \\
\hline & $4 \mathrm{~b}$ & 56 & 17.6 & -0.8 & 1.8 & 0.81 \\
\hline & $4 \mathrm{c}$ & 42 & 19.7 & 1.4 & 1.6 & 0.96 \\
\hline & $8 \mathrm{bs}$ & 17 & 16.0 & -2.4 & 1.3 & 0.82 \\
\hline & $9 b$ & 18 & 17.2 & -1.2 & 1.6 & 0.98 \\
\hline \multirow{6}{*}{$\begin{array}{l}\text { Average daily precipitation, } \\
\mathrm{mm}\end{array}$} & $2 b$ & 55 & 1.9 & -0.5 & 2.4 & 0.91 \\
\hline & $4 \mathrm{~b}$ & 56 & 1.9 & -0.5 & 2.1 & 0.90 \\
\hline & $4 c$ & 42 & 3.8 & 1.3 & 2.6 & 0.87 \\
\hline & $8 \mathrm{bs}$ & 17 & 5.1 & 2.6 & 3.3 & 0.82 \\
\hline & $10 \mathrm{a}$ & 16 & 2.0 & -0.4 & 2.4 & 0.83 \\
\hline & $13 \mathrm{~s}$ & 262 & 1.9 & -0.5 & 2.2 & 0.82 \\
\hline
\end{tabular}

anticyclone (type $7 \mathrm{~b})$. This type (7b) is responsible for more prolonged warm events. As Table 2 shows, however, it is type $4 \mathrm{c}$ which produces statistically significant warm anomalies in the region, and this is likely due to the transport of very warm air out of the Balkan region or Turkey. Additionally, type 13s has also been associated with warm anomalies, in particular the strong blocking event of summer $2010[15,26]$, but this category was also not statistically significant.

Strong cold anomalies of daily temperature were associated with circulation types $2 \mathrm{~b}, 3,4 \mathrm{~b}$, and $9 \mathrm{~b}$, which are northerly flow regimes in the region, and all of these were statistically significant except type 3 (Table 2 ). Types $2 \mathrm{~b}$ and $4 \mathrm{~b}$ occur in association with transient anticyclones moving into the region within more zonal flow, while the remaining types are associated with more meridional circulation, on the western side of a cyclone that has moved past the region. The zonal types are associated with shorter lived and weaker cold anomalies and occurred more frequently, while the meridional types are associated with the stronger, more persistent, but fewer cold anomalies (Table 2).

The summer season positive anomalies of daily precipitation in the CCR are associated with the development of circulation types $4 \mathrm{c}$ and $8 \mathrm{bs}$, each representing cyclones
(Table 2). Type $4 \mathrm{c}$ is associated with moisture from the Mediterranean region and convection in the warm sector of a cyclone, while type $8 \mathrm{~b}$ is associated with more stratiform type precipitation on the northwest side of low pressure. Circulation type $4 \mathrm{~b}$ occurred more frequently than type 8 bs. The significant negative precipitation anomalies are associated with anticyclonic conditions; types $2 \mathrm{~b}$ and $4 \mathrm{~b}$ and $10 \mathrm{a}$ are all transient type anticyclones, while type $13 \mathrm{~s}$ is often associated with long-lived blocking (Table 2). There was more than double the number of type 13s negative precipitation anomalies compared to the other three types combined, and summer season persistent blocking is associated with drought in the region [15].

This type of classification scheme for the hemisphericwide flows and their relationship to local and regional weather type may be very useful for long range prediction. In a study performed by [19] and references within, the authors show that long term climatic projections are of limited utility as these forecasts generally provide projections for very large space scales. Also, the studies of $[28,29]$, for example, demonstrated the utility for the classification of global scale flow regimes and their association with regional temperature and precipitation anomalies and flow. In [29], the authors 
TABLE 3: Elementary circulation mechanisms and anomalies of climatic parameters during the summer period (1900-2013).

Types of ECM associated with positive anomalies characteristics Types of ECM associated with negative anomalies characteristics Air temperature

$8 \mathrm{ds}, 12 \mathrm{a}, 13 \mathrm{~s}, 4 \mathrm{c}, 3,9 \mathrm{a}$ $4 \mathrm{~b}, 8 \mathrm{a}, 7 \mathrm{bs}, 2 \mathrm{~b}, 8 \mathrm{bs}, 2 \mathrm{c}$

Precipitation

$8 \mathrm{a}, 4 \mathrm{c}, 8 \mathrm{bs}, 12 \mathrm{bs}, 7 \mathrm{bs}$ $10 \mathrm{a}, 10 \mathrm{~b}, 9 \mathrm{a}, 8 \mathrm{ds}, 13 \mathrm{~s}, 3,6$, 7as

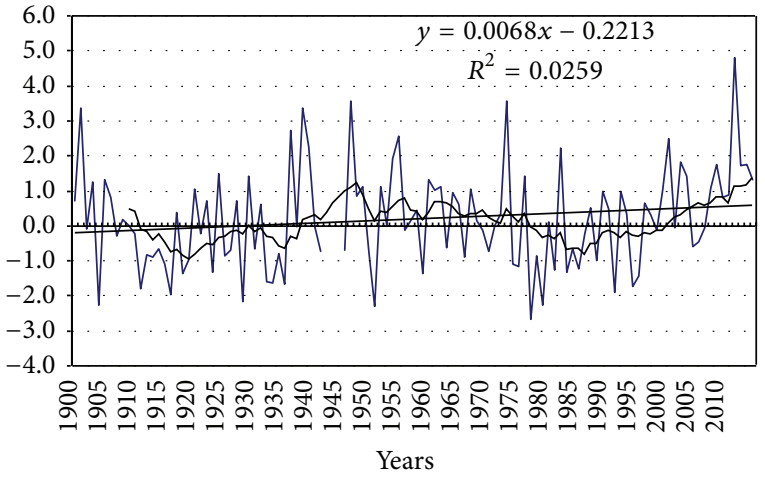

Figure 2: The mean summer season daily temperature anomalies (blue) and the 10-year running mean (black) from 1900 to 2013.

show that using the classification scheme proposed in their work could be used to make long range forecasts that showed skill above climatology. The results of this study could also provide a methodology for downscaling long range forecasts or climatic projections to the regional scale with more precise results for the expected weather types and their associated temperature and precipitation anomalies.

\subsection{Frequency of Circulation Types Compared to Tempera-} ture and Precipitation Trends. In recent years, research has examined the frequency of the occurrence of extreme events (e.g. $[4,7,12,13])$, and this is particularly true for the warm season. Heat waves and drought conditions affect the wellbeing of people [26] and the functioning of the various sectors of the economy and especially the agricultural sector $[18,19]$. Thus, a study of the frequency of occurrence of monthly temperature and precipitation anomalies was examined for the entire period at the study station (1889-2013). Here, months were chosen if the average temperature was $2^{\circ} \mathrm{C}$ or more above and below the mean (more than one standard deviation for the summer season or any summer month) and for precipitation if the month was $20 \%$ above or below the normal and these are consistent with the values used by the Russian Hydrometeorological Center [31] for defining an extreme event. The trend and variability of temperature and seasonal precipitation in summer seasons of 1899-2013 are presented in Figures 2 and 3.

The increase of the seasonal average air temperature in the summer was $0.6^{\circ} \mathrm{C}$ when comparing the 1971-2000 means with the more recent 1981-2010 period. However, the increase in temperature over the last decade is $1.3^{\circ} \mathrm{C}$, which compares to the standard deviation of the 1981-2010 summer season $\left(1.5^{\circ} \mathrm{C}\right)$. Also, at the beginning of the 21st century,

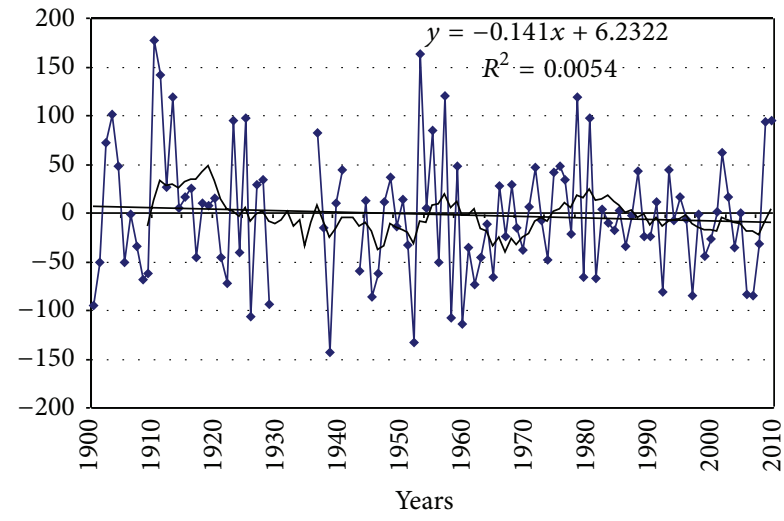

FIgURE 3: As in Figure 2, except for precipitation.

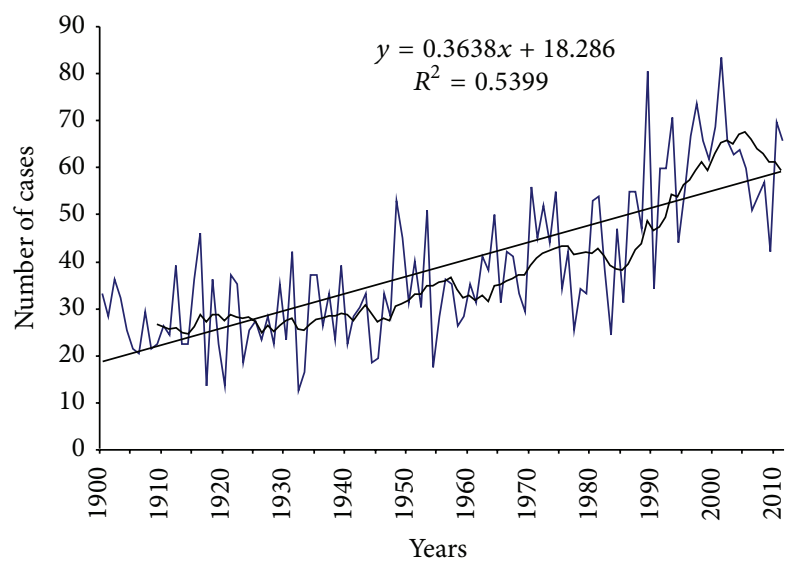

FIGURE 4: The total duration of circulation types associated with positive anomalies of temperature.

there has been a reduction in precipitation of the growing season (19 mm-9\%) for the 1981-2010 period compared to the previous period, 1971-2000, and precipitation variably increased ( $3 \mathrm{~mm}-5 \%)$. The increase in variability is consistent with the results for the Midwest USA, but there has also been an increase in precipitation for that region [3].

Table 3 shows the circulation types which occur during the summer months whether or not they produced anomalies that were statistically significant. The total duration of circulation types associated with positive temperature anomalies during the summer season has been increasing steadily since the early 1900s in the study region (Figure 4). Since the early 1900 s the number of these has approximately doubled and the trend is statistically significant at the $99 \%$ confidence level when applying an F-test (e.g., [32]). While Figure 2 


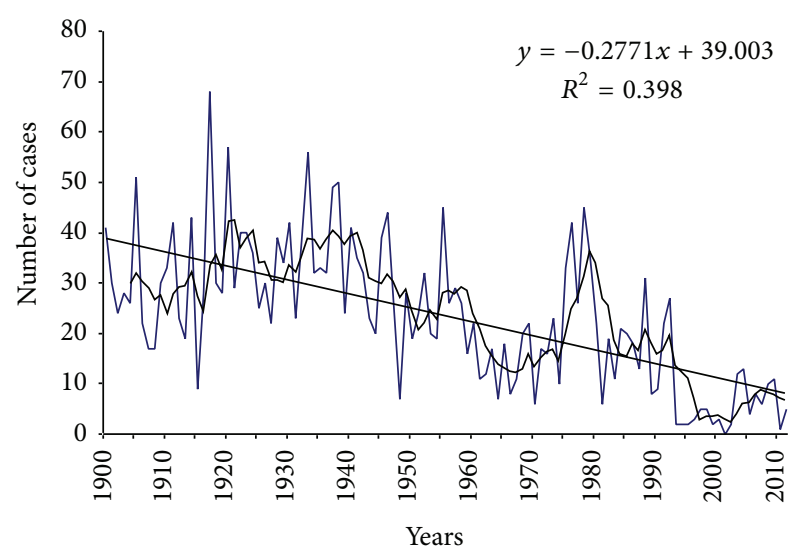

FIGURE 5: As in Figure 4, except for negative anomalies of temperature.

exhibits a trend similar to overall global temperatures (e.g., [6]), Figure 4 does not. This is likely reflecting the fact that there are changes in the character of large-scale flow regime, which may not always correspond to temperature, especially regionally (see Table 1; see also [3]).

The most significant changes in the occurrence of circulation type over the region for the duration and magnitude of warm anomalies have been the increased occurrence of circulation types $13 \mathrm{~s}, 9 \mathrm{a}$, and $8 \mathrm{ds}$. Note that these are only the occurrence of a particular type of flow regime and not the strength of the warm anomaly produced (Table 2). In addition to type $13 \mathrm{~s}$, circulation type $9 \mathrm{a}$ is also associated with blocking in the study region. In the study of [15], the authors demonstrated that drier summers were associated with more persistent and stronger blocking over the sector $20^{\circ} \mathrm{E}$ to $60^{\circ} \mathrm{E}$, when examining interannual variability. Their study did not examine the regional trend in overall blocking occurrence. Accessing the blocking archive found at the University of Missouri (http://weather.missouri.edu/gcc/) and using the criterion of [15], the number of blocking events in the region increased during the February-August and June-August time frames from approximately four and two events per year during the decade of the 1970s to about five and three events per year during the 2000s, respectively. However, the number of blocking days increased dramatically from 32 and 13 days in the 1970 s to 54 and 30 days in the 2000s, respectively, an increase significant at the $99 \%$ confidence level. This increase in blocking is consistent with the result shown in Figure 4 and the increased occurrence of types such as $13 \mathrm{~s}$.

Circulation type $8 \mathrm{~d}$ is mainly a surface anticyclone event. Concurrent with the increase in warm anomalies, there have been a decrease in the occurrence of strong cold anomalies and a reduction in the number of circulation types associated with cold anomalies (Table 3, Figure 5). The flow of cold air into the region is associated with strong northerly flow on the eastern (western) side of high (low) pressure, and these processes are no longer for the summer period.

The assessment of moisture conditions at the turn of the 20th and 21st centuries yielded ambiguous results. Changes in precipitation amount and frequency driven by the increase of the role of convectively driven events in comparison

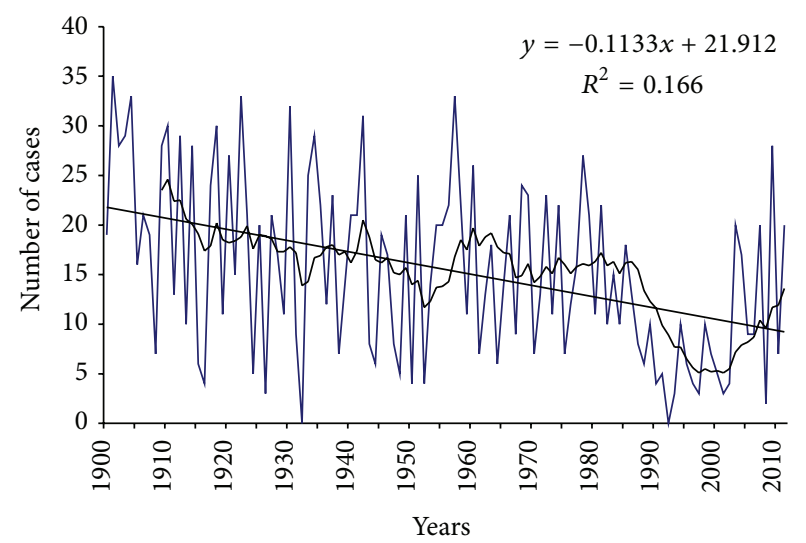

FIGURE 6: The total duration of circulation types associated with positive anomalies of precipitation.

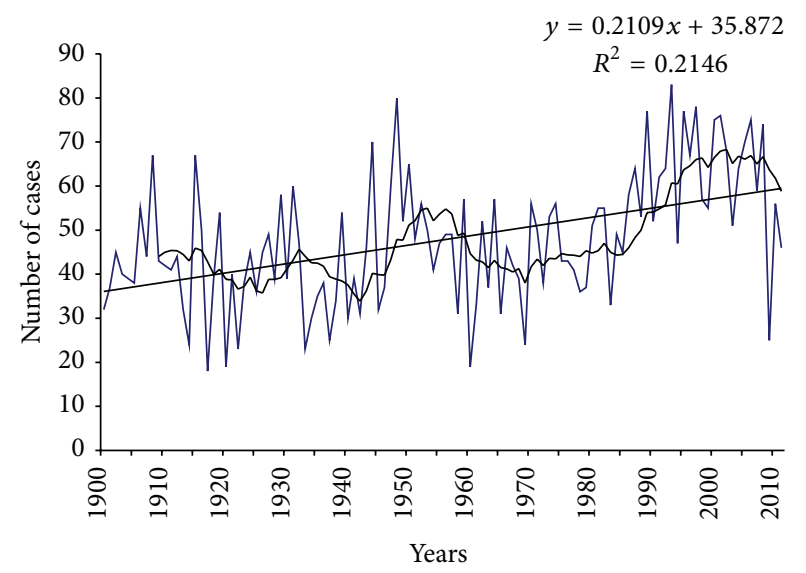

FIGURE 7: As in Figure 6 except for negative anomalies of precipitation.

with steadier stratiform type precipitation were the reason for these results (Figures 6 and 7). The increase in the frequency of occurrence of cyclones from the southwest (e.g., type 4c), often associated with convection (and heavier rainfalls), has been associated with less frequent rainfalls and decreased monthly totals of summer season precipitation. Concurrently, the number of days with transient anticyclones (e.g., type 4b) has decreased dramatically. Also, as for the warm temperature anomalies, types $13 \mathrm{~s}$ and $9 \mathrm{a}$ associated with blocking have been associated with the rise in negative precipitation anomalies. Thus, summer season precipitation has been more variable over the region, especially in the latest 10 years, a result similar to that in central US plains region [3]. Such a result makes agricultural production more difficult, especially for those crops that need consistent precipitation.

\section{Summary and Conclusions}

A study of the summer season climatological character of temperature and precipitation in the CCR of Russia was carried out using temperature records from the BelgorodskoeFenino weather station. This station represented broadly the 
synoptic scale conditions across the CCR, which is an agriculturally important region of western Russia. An analysis of the general trends was performed briefly but can also be found in other studies for this region [12-14]. The summer average temperature increased by $0.6^{\circ} \mathrm{C}$ when comparing the $1971-2000$ means with the $1981-2010$ values and by $1.3^{\circ} \mathrm{C}$ in the most recent decade. The amount of precipitation during the summer season has decreased since the beginning of the twenty-first century and when using the same comparison for 30-year periods of temperature. While precipitation was characterized by less variability in the second half of the twentieth (20th) century in comparison with the first half of the twentieth century, there was an increase in variability in recent decades.

However, this study is unique in that it presents a hemispheric scale flow regime classification system that has not been presented to the general meteorological community previously. This classification scheme has 13 general hemispheric configurations and many of these have variants related to the position of the major trough and ridge systems in the jet stream or the strength of these in the warm season versus the cold season. There are a total of 42 variants, and these are then related to synoptic scale weather conditions across the CCR and classified generally as cyclonic or anticyclonic conditions depending on the dominant surface system. These flow regimes can even be related to large-scale features such as blocking anticyclones, which can influence weather over large regions for long periods of time (e.g., [2, 7, 15, 24, 26]). This work also demonstrated that this NH classification scheme has the potential for use in downscaling long range forecasts or climate projections to the regional level with more precise temperature and precipitation projections based on contingency.

In this work, for the CCR it was found that several types of large-scale weather regimes produce warm anomalies over this region during the summer. Most are associated with anticyclones, either long-lived stationary surface anticyclones to the east or blocking. However, the weather regime that produced the strongest warm anomalies with the highest statistical significance was associated with the warm sector of a cyclone over the region. Also, there have been a steady increase in the occurrence of warm anomaly regimes since 1900 and a statistically significant increase in the occurrence of blocking in the $20^{\circ} \mathrm{E}$ to $60^{\circ} \mathrm{E}$ sector of the Northern Hemisphere during the last 40 years. Additionally, since the early 1900s, the probability of weather regimes producing heat waves has doubled. Conversely, the occurrence of cool temperature anomalies during summer has decreased, and the occurrence of strong, long-lived cold air outbreaks is no longer typical.

There are also several types of weather regimes that produce anomalously dry and wet conditions in the CCR. It was found that cyclonic regimes were associated with anomalously wet conditions, and both transient and stationary anticyclones, including blocking, are associated with dry anomalies. An increase in flow regimes favoring more convective type precipitation has occurred in concert with a decrease in synoptic types that produce more steady (stratiform) rainfall. The result has been a decrease in summer precipitation in the last few decades and since 1900. This trend in precipitation is opposite to that of the precipitation trend in the agriculturally important areas of the central USA. Also, in the last few decades precipitation variability has been greater than the earlier periods, and this is also associated with the increase in blocking events during the summer season.

\section{Conflict of Interests}

The authors declare that there is no conflict of interests regarding the publication of this paper.

\section{Acknowledgments}

This research is supported by Russian Scientific Foundation, Project no. 14-17-00171, and the Council for International Education/Fulbright Scholarship Program.

\section{References}

[1] J. M. Wallace and D. S. Gutzler, "Teleconnections in the geopotential height field during the Northern Hemisphere winter," Monthly Weather Review, vol. 109, no. 4, pp. 784-812, 1981.

[2] D. Barriopedro, R. García-Herrera, A. R. Lupo, and E. Hernández, "A climatology of Northern Hemisphere blocking," Journal of Climate, vol. 19, no. 6, pp. 1042-1063, 2006.

[3] K. Birk, A. R. Lupo, P. E. Guinan, and C. E. Barbieri, "The interannual variability of midwestern temperatures and precipitation as related to the ENSO and PDO," Atmosfera, vol. 23, no. 2, pp. 95-128, 2010.

[4] V. A. Semenov, M. Latif, D. Dommenget et al., “The impact of North Atlantic-Arctic multidecadal variability on Northern Hemisphere surface air temperature," Journal of Climate, vol. 23, no. 21, pp. 5668-5677, 2010.

[5] J. Sillmann, C.-M. Mischa, M. Kallache, and R. W. Katz, "Extreme cold winter temperatures in Europe under the influence of North Atlantic atmospheric blocking," Journal of Climate, vol. 24, no. 22, pp. 5899-5913, 2011.

[6] Intergovernmental Panel on Climate Change (IPCC), "Climate change 2013: the physical scientific basis," in Contributions of Working Group I to the Fifth Assessment Report of the Intergovernmental Panel on Climate Change, Intergovernmental Panel on Climate Change (IPCC), 2013, http://www.ipcc.ch.

[7] I. I. Mokhov, A. V. Timazhev, and A. R. Lupo, "Changes in atmospheric blocking characteristics within Euro-Atlantic region and northern hemisphere as a whole in the 21st century from model simulations using RCP anthropogenic scenarios," Global and Planetary Change, vol. 122, pp. 265-270, 2014.

[8] J. A. Johnstone and N. J. Mantua, "Atmospheric controls on northeast Pacific temperature variability and change, 19002012," Proceedings of the National Academy of Sciences, vol. 111, no. 40, pp. 14360-14365, 2014.

[9] I. I. Mokhov, D. V. Khvorostyanov, and A. V. Eliseev, "Decadal and longer term changes in El Niño-southern oscillation characteristics," International Journal of Climatology, vol. 24, no. 4, pp. 401-414, 2004.

[10] A. Gershunov and T. P. Barnett, "Interdecadal modulation of ENSO teleconnections," Bulletin of the American Meteorological Society, vol. 79, no. 12, pp. 2715-2725, 1998. 
[11] A. N. Zolotokrylin and T. B. Titkova, "The dependence of the climate anomalies in the growing season forest on the Russian plains on large-scale atmospheric circulation," Izvestia, Seria Geography, vol. 5, pp. 121-128, 1998.

[12] M. G. Lebedeva and O. V. Krymskaya, "Extreme temperature regimes in the Central Black Earth region," in Proceedings of the International Scientific Seminar on Climate Change, Soil and Environment, pp. 9-16, KOHCTAHTA, Belgorod, Russia, 2009.

[13] A. N. Petin, M. G. Lebedeva, O. V. Krymskaya, Y. G. Chendev, A. G. Kornilov, and A. R. Lupo, "Regional manifestations of changes in atmospheric circulation in the central black earth region (by the example of Belgorod region)," Advances in Environmental Biology, vol. 8, no. 10, pp. 544-547, 2014.

[14] Y. G. Chendev, A. R. Lupo, A. N. Petin, and M. G. Lebedeva, "Influence of long- and short-term climatic changes on chernozem soils: central Chernozem region of Russia," Papers in Applied Geography, vol. 36, pp. 156-164, 2013.

[15] A. R. Lupo, I. I. Mokhov, Y. G. Chendev, M. G. Lebedeva, M. Akperov, and J. A. Hubbart, "Studying summer season drought in Western Russia," Advances in Meteorology, vol. 2014, Article ID 942027, 9 pages, 2014.

[16] C. D. Ahrens, Meteorology Today: An Introduction to Weather, Climate, and the Environment, Brooks-Cole, 10th edition, 2012.

[17] S. P. Khromov and M. A. Petrosyants, Meteorologia i klimatologia, Publication of Moscow State University, 2006.

[18] M. C. Stambaugh, R. P. Guyette, E. R. McMurry, E. R. Cook, D. M. Meko, and A. R. Lupo, "Drought duration and frequency in the U.S. Corn Belt during the last millennium (AD 992-2004)," Agricultural and Forest Meteorology, vol. 151, no. 2, pp. 154-162, 2011.

[19] J. D. H. Keatinge, D. R. Ledesma, F. J. D. Keatinge, and J. D. A. Hughes, "Projecting annual air temperature changes to 2025 and beyond: implications for vegetable production worldwide," Journal of Agricultural Science, vol. 152, no. 1, pp. 38-57, 2014.

[20] Daily Records from in the Belgorod Center for Hydrometeorology and Environmental Monitoring (1890-2013), available from The Russian Hydrometeorological center.

[21] N. K. Kononova, The Classification of the Northern Hemisphere Circulation Mechanisms Using the Methods of BL Dzerdzeevsky, Voentekhinizdat, Moscow, Russia, 2009.

[22] N. K. Kononova, "The Dynamic circulation of the atmosphere in the 20th century and the start of the 21st century," 2013, http://www.atmospheric-circulation.ru/.

[23] E. Kalnay, M. Kanamitsu, R. Kistler et al., "The NCEP/NCAR 40-year reanalysis project," Bulletin of the American Meteorological Society, vol. 77, no. 3, pp. 437-471, 1996.

[24] J. M. Wiedenmann, A. R. Lupo, I. I. Mokhov, and E. A. Tikhonova, "The climatology of blocking anticyclones for the Northern and Southern Hemispheres: block intensity as a diagnostic," Journal of Climate, vol. 15, no. 23, pp. 3459-3473, 2002.

[25] J. C. Rogers, "The association between the North Atlantic Oscillation and the Southern Oscillation in the Northern Hemisphere," Monthly Weather Review, vol.112, no. 10, pp. 19992015, 1984.

[26] A. R. Lupo, I. I. Mokhov, M. G. Akperov, A. V. Chernokulsky, and H. Athar, "A dynamic analysis of the role of the planetaryand synoptic-scale in the summer of 2010 blocking episodes over the European part of Russia," Advances in Meteorology, vol. 2012, Article ID 584257, 11 pages, 2012.
[27] H. Harms, "Snow forecasts for Southeast Wisconsin," NOAA Technical Memorandum NWSTM CR-38, US Department of Commerce, NOAA NWS, 1970.

[28] A. R. Lupo, E. P. Kelsey, D. K. Weitlich et al., "Interannual and interdecadal variability in the predominant Pacific region SST anomaly patterns and their impact on climate in the midMississippi valley region," Atmosfera, vol. 20, no. 2, pp. 171-196, 2007.

[29] A. R. Lupo, E. P. Kelsey, D. K. Weitlich, N. A. Davis, and P. S. Market, "Using the monthly classification of global SSTs and 500 $\mathrm{hPa}$ height anomalies to predict temperature and precipitation regimes one to two seasons in advance for the mid-Mississippi region," National Weather Digest, vol. 32, no. 1, pp. 11-33, 2008.

[30] C. L. Berger, A. R. Lupo, P. Browning, M. Bodner, M. D. Chambers, and C. C. Rayburn, "A climatology of northwest Missouri snowfall events: long-term trends and interannual variability," Physical Geography, vol. 23, no. 6, pp. 427-448, 2002.

[31] Manual on Service Forecasts, Section 2, part 6, Moskovskaya Gidrometeoizdat Department, 1986.

[32] J. Neter, W. Wasserman, and G. A. Whitmore, Applied Statistics, Allyn \& Bacon, Boston, Mass, USA, 3rd edition, 1988. 

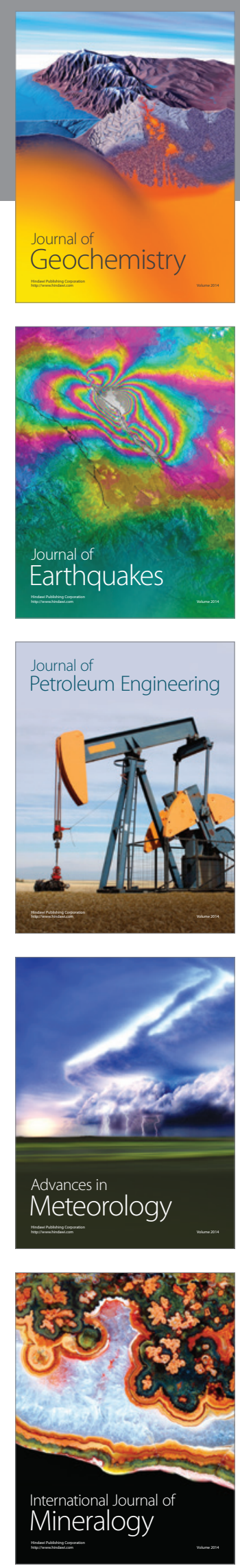
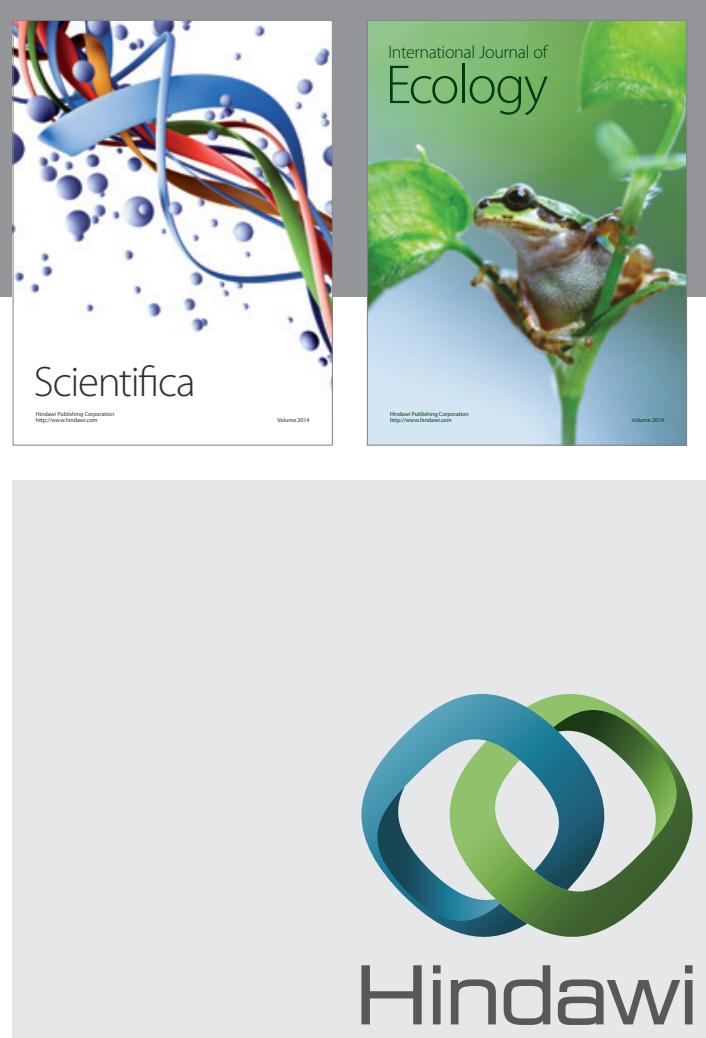

Submit your manuscripts at

http://www.hindawi.com
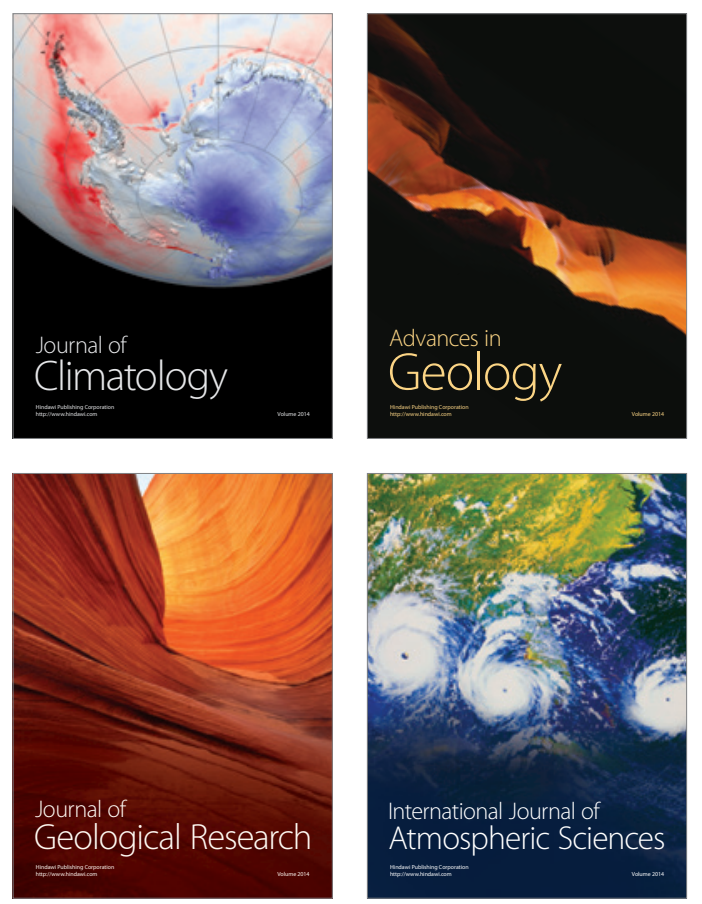

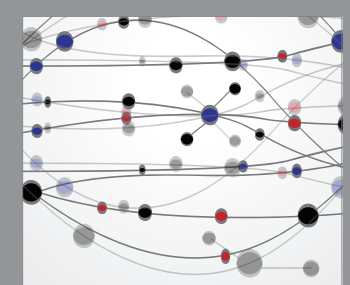

The Scientific

\section{World Journal}
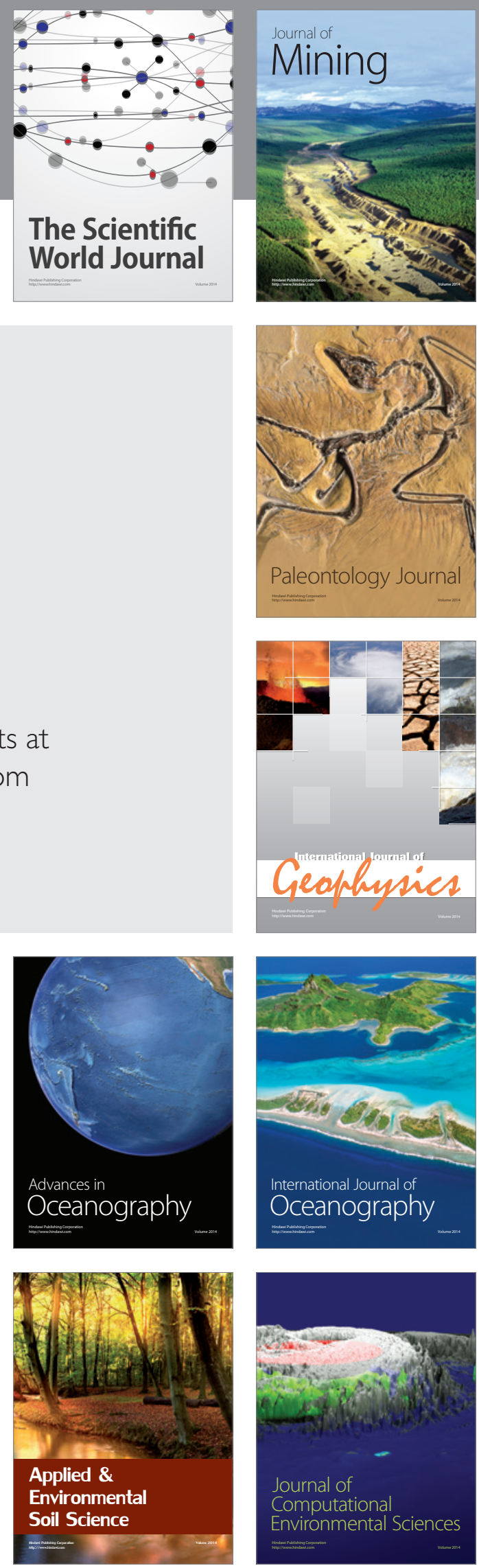